\title{
International Labor Organizations, 1864-1997: The Weight of History and the Challenges of the Present
}

\author{
byDimitris Stevis \\ Colorado State University
}

Cite: Stevis, Dimitris. (1998). "International Labor Organizations, 1864-1997: The Weight of History and the Challenges of the Present." Journal of World-Systems Research http://jwsr.ucr.edu/4: 52 - 75 .

(C) 1998 Dimitris Stevis.

[Page 52]

Joumal of World-Systems Research

\section{$\underline{\text { Introduction }}$}

Deepening neoliberal integration, the end of the Cold War, and the decline or compromise of communist and socialist parties, offer a window of opportunity for international labor politics. Why is it, then, that the comprehensive network of global and regional labor organizations continues to play a marginal role, even though they are clearly conscious of these developments and have sought to respond to them? The answer to this question has important practical and theoretical implications. My general goal, therefore, is to situate the contemporary predicament of international labor organizations within its historical context. Activists would like to know whether labor organizations are basically sound but need to be reformed or fundamentally unsuitable for a vital international labor politics. Theoretically, international labor organizations provide us with a rich record through which to investigate cross-border relations at the level of society and state-society relations.

Two assumptions guide this enterprise. The first is that we should recognize that labor has been an active participant in the tragedies and victories that have affected it. While broad historical characteristics and dynamics clearly leave their imprints, the specific ways in which they do so contain strong elements of historic contingency. Most importantly, we should not fall prey to a manichean attitude that locates emancipation in society and oppression in the state. It is always wise to ask what kind of society and what kind of state.

The second assumption is that activists and unions must confront the question of both organizing and organizations. The tactical or strategic evocations of social movement unionism and societal politics should not diminish the importance of organizations in our minds. Yet, because it is not any kind of organization that a vital and emancipatory politics should aspire to, it is necessary to make organizational questions central to labor 
politics. The present account focuses primarily on those factors that have contributed to the shaping of international labor organizations.

In order to provide a systematic comparison of the various periods of international labor organizations I focus on two dimensions and investigate any relations between them. For the sake of convenience I call one dimension political and the other organizational.

Labor politics may be distinguished in terms of the varying approaches towards capitalism and the state system. Broadly speaking labor ideologies may be supportive of capitalism or may seek to reform or transform it. But, each of these categories can accommodate a variety of historical choices. For instance, reform of capitalism may be socialdemocratic or corporatist. Transformation may be syndicalist or revolutionary socialist. Similarly, labor views on the nature of the state and state system vary. Some labor ideologies and movements have been very supportive of the state system for nativist reasons while others have seen it as a shield against intervention; others have sought to transcend the state either by rejecting its primacy or by proposing alternative units of social organization.

The internal politics of labor is also significant (for a pioneering study see Harrod 1972). By internal politics I refer to the relations between labor unions and their historic political allies and within labor movements and unions. Union-party relations have historically affected the domestic and the international politics of unions; domestic organizational characteristics have also influenced preferences regarding international organizat ions.

[Page 53]

Journal of World-Systems Research

Organizationally, labor organizations may be distinguished with respect to their membership and their autonomy. In terms of membership, organizations may consist of single national units with exclusive rights of representation; alternatively, they may allow multiple national units. Organizations in which access to individual and groups is mediated by national 'gatekeepers' may be called intersocietal. On the other hand, organizations that allow direct membership by individuals or groups can be labelled transocietal. Membership choices are not accidental, as we will see.

Equally important is the autonomous capacity of labor organizations. In some instances, the primary goal of an organization may be to legitimate the autonomy of the constituent units, whether national or subnational. Usually these are weak confederations (basically the mirror of interstate politics at the level of society). In other instances organizations are given various federal powers over the units. In still other instances, the organization may be given significant supraunit powers, with the autonomy of the units commensurably limited. These organizations may labelled unitary. 
Historically, certain political and organizational choices go together. These affinities are not immutable, however, as tactical and strategic reasons may force dissociation. Most importantly, over time there is frequently a disarticulation of such affinities. While revolutionary socialists (Marxists), for instance, were in favor of autonomous labor organizations the Bolsheviks were not. While the Third International was a unitary organization its membership was intersocietal.

[Page 54]

Journal of World-Systems Research

For the purposes of this paper I have identified five periods reflecting, as much as possible, major patterns in transborder labor politics. Within each period I focus on the political and organizational factors that characterize the period, articulating the discussion around the organizations of the period. As a consequence, there is no effort at providing a comprehensive account of international labor politics. The first period covers up to the late 1880s, just before the "New International" (later known as the Second International) and the first International Trade Secretariat were formed; the discussion focuses on the First International. The second period covers from the 1890 s to the end of WWI with the collapse of the Second International, and the divisions in the world socialist and labor movements. The emergence of the International Trade Secretariats and the International Federation of Trade Unions are the major results of this period. The third period covers from the reconstitution of the International Federation of Trade Unions in 1919 to the formation of the World Federation of Trade Unions in 1945. The efforts at making the IFTU more than a loose confederation and the reasons behind the ultimate failure are central to this period. The fourth period covers the apex of the Cold War, from 1945 to the late 1960s. The hegemonic role of the AFL-CIO characterizes this period. The last period covers the years since and is characterized by both a slow healing of some historical divisions within the labor movement and the resurgence of some international labor organizations. Somewhat more attention is given here to the internal and external challenges confronting international labor.

\section{International Labor Organizations, 1864-1997}

\section{Labor Organizations Before 1889: Contesting Interstate Politics And Capitali sm}

Formation and Characteristics of the First International (FI). What led the various domestic, émigré, and international organizations to create the International Working Men's Association on September 28, 1864?2 As far back as the 1830s there were calls and programs for international action, variably rooted in liberal cosmopolitanism, radical political ideologies, the shared experiences of skilled workers, or British union concerns over the importation of "scab" labor from the Continent (Braunthal 1967a, Part 1).

The First International, therefore, was formed on the foundations of a number of previous attempts and brought together organizations with different political and organizational 
preferences. Although proposed, it did not limit itself to manual workers nor did it reject political groups as distinguished from unions. The sections of the FI were of two types. Individuals could form groups and join the FI directly. Existing organizations, whether unions or parties, could also join, thus making their members part of the International. Although the rules of the FI encouraged domestic coordination and unification, they did not require so.

The leadership of the organization was in the hands of the Governing Council, which was elected by the annual Congresses. The Governing Council reflected the national origins of the organization but there was no provision for a specified percentage of members from each country. Similarly, each section elected delegates to the Congresses, which in turn elected the Council. The responsibilities of the Council were to provide a forum for the exchange of information and the discussion of national and local issues and, increasingly, to shape an agenda for working-class politics and action. As it developed, the Council also gained powers over membership, including the right to expel members. Contests over the powers of the Council, along with the deep disagreements over the Paris Commune of 1871, were two important reasons why the FI fell apart in the early 1870 s.

[Page 55]

Journal of World-Systems Research

In general, the membership of the FI was transocietal with some federal powers given to the Council. What accounts, then, for the transocietal nature of the FI? I have already alluded to some key reasons. One factor was the absence of national union centers or even political parties that could control access to their own societies. The second factor was the continued contestation of the nature of interstate politics and of capitalism by some of the leading ideologies of the times, including the Marxists and the anarchists. A third factor, however, was the absence of significant domestic or international labor legislation that would render domestic or interstate politics a practical avenue for a strong enough tendency within the labor movement (for domestic labor policies see de Vries and de Vries 1948; for information on international labor policies before WWI see US Bureau of Labor Statistics 1919; Low 1921). As domestic policies of some relevance to labor started becoming reality, however, they gave the least internationalist elements a pragmatic alternative.

Undeniably, in hindsight the First International seems much closer to some of the ecological organizations of today. Within its limited means it engaged in cross-border activism (Knudsen 1988), promoted the formation of labor organizations, had significant ideological prestige and impact, and put the idea of labor internationalism on labor's agenda. Yet, we must recognize the historical factors that accounted for its specific characteristics. Clearly, it refused to give political parties power over labor unions and was critical of both capitalism and the role of the state. But, then again, there were no 
significant political parties and unions that claimed to represent the working class of whole countries nor were there labor policies. This was not the case thirty years later.

\section{From the 1890s To WWI: Resisting Capitalist Hegemony, Contesting Labor Politics}

Changing State Policies. By the early 1890s there were in place a number of national union centers (federations) and parties, while states had put in place or were considering domestic labor policies (de Vries and de Vries 1948). Domestically, the increased role of parliaments raised additional opportunities for action or co-optation for workers (See Mann 1993, Chs. 17-19). These changes in domestic politics led unions and parties to further place their energies on reforming domestic politics--not an unreasonable strategy (Tilly 1995; Esping-Andersen 1990).

Internationally, states started negotiating labor legislation. It is not surprising that the first governmental meeting on the subject was called the year after the first meeting of the Socialist International. Precious little was accomplished at the international level before WWI, however. Most significantly, the direct participation of unions in policy-making was kept to a minimum (Low 1921; US Bureau of Labor Statistics 1919). The representation of labor, instead, passed to policy professionals generally not associated with unions and many hostile to them. These professionals soon formed the International Association for Labor Legislation and its International Labor Office (Low 1921; Shotwell 1934).

[Page 56]

Journal of World-Systems Research

Socialist Politics. The most important development of this period, from the point of view of labor politics, is the emergence to hegemony within Continental radicalisin of the German Social Democratic Party (Braunthal 1967/1961; Cole 1960; Lorwin 1929, Ch. 3). The "New [Second] Socialist International" was timidly conceived in 1889 even though, as the title suggests, its was thought of as a successor of the First International. Thus, during the 1890 s its contacts were through international meetings. It was not until 1900 that the International Socialist Bureau was established and the SSI started moving towards strong confederalism. The Bureau grew significantly in resources and importance but the periodic Congresses of the International remained the main manifestations of its importance and politics.

The SSI was intended as an organization of national political parties rather than an ecumenical umbrella to include unions, groups and individuals. Only one party from e ach country could participate, although there were unavoidable exceptions where there were no parties, such as France. The organization's intersocietalism was intended to achieve political harmonization around socialist principles and prevent domestic divisions. As a result, those national organizations that were accepted could exclude competitors. In fact, that may have been the primary reason that led some to join. 
The principal political characteristic of the SSI was the explicit programmatic goal of socialist parties to attain and reform state power and capitalism domestically. Increasingly according to the conventional reading, this goal overcame any thoughts about transforming international politics (Armstrong 1942). Given the disaster of WWI, this reading is largely justified. A closer look suggests that there were major differences both within the SSI and specific parties (see Wheeler 1977, as well as the sources for the immediate post WWI period below).

Organizational Forms of International Labor Politics. Notwithstanding the influence of social democracy, the origins of international labor organizations were more diverse than the Second International. British trade-unionists, AFL craft-unionists, French syndicalists as well as various Christian and anarchist labor organizations played a role in shaping international labor organizations before WWI. Beginning in 1889 a number of sectoral international labor organizations were formed, known as the International Labor Secretariats (ITS) (see Rutters 1990; Macshane 1990; Neuhaus 1982; Lorwin 1929, Ch. 4). 3 By 1914 there were 28 Secretariats, 24 of them based in Germany. They were overwhelmingly European, but after 1904 a growing number of US unions joined. The Secretariats were organized across craft-lines and brought together national labor organizations. More than one national organization was allowed only in exceptional circumstances. As the case of one of the best organized amongst them suggests, that of the typographers, the members were hesitant to establish strong federal organizations (Reberieux 1990). This reflected both the misgivings of the Social Democrats as well as the concern of the British trade unions, and increasingly the AFL, that strong ITSs would further enhance the hegemony of the German unions.

During the period before WWI the ITSs were clearinghouses limited to trade unionist, and not political, activities. Support activities were exceptional and there were no efforts at common organizing campaigns. Some of them--such as the International Transport Federation--were becoming more centralized and streamlined, reflecting the organizational predilections of German unionists. At no time in their early or subsequent history, however, did the ITSs see themselves as federal or transocietal unions.

The sectoral characteristics of the ITSs and the bias of the SSI towards political parties led to the formation of the International Secretariat of Trade Unions Centers in 1901. The Secretariat was formed under the political and organizational shadow of the Second International in order to accommodate both socialist trade unions as well as unions with no parties, such as the French Confédération Générale du Travail (CGT) and the AFL, or with weak parties, such as the British trade unions. The Secretariat adopted a policy of single membership from every country. This policy was biased in favor of socialist leaning unions and clearly against radical syndicalists.

[Page 57]

Joumal of World-Systems Research 
In the period up to WWI the Secretariat, which became the International Federation of Trade Unions (IFTU) in 1913, focused on the gathering and the dissemination of information about labor unions and the creation of focal sources of information and communication (Sassenbach 1926; Schevenels 1956, Chs. 1 and 2; and Milner $1990 \mathrm{Ch}$. 4). By the time of WWI it had a growing multinational staff, information gathering and dissemination had been regularized, and some strike support funds were being collected and distributed. The IFTU, however, had not established any common strategies regarding the importation of "scab" labor into the Continent (particularly Germany), had not formulated a position vis-a-vis the emerging international labor legislation and had not managed to harmonize the union membership rights of migrant workers. Much of the opposition towards the organizational strengthening of the IFTU came from the AFL and its supporters in the British unions. This does not mean, however, that this weak organization did not play a major role in shaping international labor politics. It did so not by establishing a common ideology or labor discourse, but by assisting in the narrowing of labor discourse and practices. 4

Establishing a common discourse within the IFTU proved more challenging than establishing an umbrella organization. Neither the British unions nor the AFL ever adopted socialism or the union-party strategy of the Germans. The Secretariat did have an impact on French and US syndicalism however (for background on these movements see Moss 1976 and Brissenden 1919). This it did in two different ways. First, it blunted the more militant transocietalism of the syndicalists; second, it helped transform the domestic balance away from radical syndicalism (Milner 1990).

French syndicalists had centered their international policy around the idea of preventing war. Accordingly, in the event of war labor unions should be prepared to paralyze the military machinery. While the German Free Unions and social democrats also professed the same priority they resisted the calls of the French syndicalists to form a plan for action. The ultimate victory of the socialists eliminated the influence of the largest European center that followed neither the union-party approach of social democracy nor the trade unionism of the British and the AFL (for comparison, see Mommsen and Husung 1985).

In an effort to prevent the Industrial Workers of the World (IWW) from joining the Secretariat and gaining the prestige associated with it, the hitherto lukewarm AFL applied and was admitted in 1911, even though its application was received later than that of the IWW (Milner 1990: 113-114). This latter choice delegitimated the organization of single transocietal unions. The notion of a transocietal union whose aim is to build an alternative vision of domestic and international policies has not received much attention, as is always the case with defeated options. During the late 19 th and early 20 th centuries, however, it was an option. Although syndicalism was most prominent in Europe, it was the American IWW that sought to create a transocietal union by establishing chapters in Mexico, Chile, and Australia.

Thus, it was not only the strategy of transocietal labor unions of the IWW that was defeated and delegitimated; it was also the ideological transocietalism of the French 
syndicalists. In general, then, the nature of international labor organizations was affected by the increasing role of the domestic arena in labor politics as well as ideological and strategic differences amongst unions. There was no a priori external reason, in my view, why international labor organizations should have ended up as intersocietal as they did, as opposed to becoming federal. In fact, there is evidence of some movement in that direction.

\section{The Interwar Period: Contesting World Politics and Each Other}

The interwar period is considered an era of growing statism. While this is a period of increased state autonomy it should not escape our attention that this is also an era during which societal transformations and contestations are at the roots of state transformations. The USSR, Italy, Germany, Italy, a number of South American countries, Spain, and many other states were rendered powerful in the hands of victorious societal forces rather than through their own aboriginal means. $\underline{5}$

The impact of state policies on labor during this period ranges from the adoption of domestic and international policies to the forcible dissolution or corporatization of unions. In addition, the polarization of international politics was as much internal as external to labor organizations.

[Page 58]

Joumal of World-Systems Research

It is during this era that some of the strongest labor and related organizations came into existence and contested labor politics, if ultimately to the detriment of all contestants except the AFL. Labor very much participated in the unfolding of its own tragedy. $\underline{6}$

The Reconstitution of the IFTU. The Second International was decimated by WWI and has never recovered, although it has been in almost continuous existence ever since (Braunthal 1980/1971). Its collapse left labor with international tasks for which it had not been prepared. Neither ideologically nor organizationally was it ready to play the leading role that the vacuum left, while its tasks were rendered more difficult by the divisions of WWI (Horne 1991, particularly Ch. 8; Van der Slice 1941).

The IFTU was formally constituted at the Amsterdam Congress of 1919, "in the first international trade union congress ever held" (Lorwin 1929, 191).7 Organizationally it brought together the national centers of the member countries. No individual unions were allowed to join. Its activities were to take place through regular congresses with the number of delegates reflecting the size of national unions--but not proportionally as the AFL and its British allies demanded. In addition the IFTU was equipped with standing organizational forms whose role was to not only improve communications amongst the members, but to also initiate a labor agenda as well as coordinate collective action. Decision making was to be by majority rather than unanimity, as the AFL preferred. Dues 
were kept lower than continental unions demanded because of the opposition of the AFL and its British allies. In short, the IFTU was envisioned as a more federal organization than its predecessor; due to internal opposition, however, it did not become as strong as the socialists would have liked it to be.

In the immediate post war years the IFTU was active and determined in establishing its hegemonic role within the labor movement, taking its position at the ILO as the representative of labor, advancing proposals for post-war reconstruction and engaging in major actions in response to policies in Hungary and Poland. Overall, the IFTU represents what Lorwin called "reformist internationalism" $(1929,395)$. As early as 1919 , the formation of the ILO took the wind out of the socialists' 'supranationalist' visions; by 1922 the divisions within the world's labor movement broke down its prospects of becoming a hegemonic organization within socialist civil society. By the time of the 1926 British miners' strike the divisions were already far too deep.

Politics from the Right and the Formation of the ILO. The most significant development in interstate and intersocietal labor politics was the ILO. Some type of international labor organization had been on the agenda of pre-war socialists and labor organizations. They had in mind a strong federal type of organization in which labor would play a hegemonic role--to be developed from the International Labor Office of the International Association for Labor Legislation--that would represent and promote the interests of labor. The post-war radicalization of labor politics and the appeal of revolutionary socialism, motivated governments--in collaboration with 'right wing' victorious socialists, AFL and British business unionists, and labor professionals --to negotiate a significantly less powerful organization in which labor was clearly a junior partner (Shotwell 1934 for background; Van der Slice 1941). The final result was opposed by the IFTU as it fell short both in terms of its policy goals and in terms of its capacity to pass and implement labor legislation.

Even though the social democrats and the IFTU did not get what they wanted out of the ILO they participated actively in its operations (Schevenels 1956). The ILO's tripartite arrangement and its rather limited mandate, however, solidified a consultative type of global corporatism. Nonetheless, the ILO remains an oddity amongst IGOs, a fact that recommends a closer look at the debates and contestations that informed the post WWI move towards international organizations.

Politics from the Left. The formation of the communist Third International in the Spring of 1919 is a significant event in interwar politics. While it started as an organization that would include both parties and unions it eventually became an organization of parties and one that took party-union relationship to one of thorough primacy of the party. $\underline{8}$ 
Its bitter trajectory has obscured its organizational boldness (Carr 1982). The Third International demonstrates both the possibilities and the dangers of a unitary organization. Its impacts on domestic and international politics were momentous; in the end, because of its cohesion it succumbed as a whole to the authority of the Soviet State. 9

Originally, the communist parties and trade unionists did not wish to establish a separate international labor organization nor break up existing nation al organizations; instead they hoped to radicalize and lead existing organizations. Partly in response to the concerns of the syndicalists and partly in response to the IFTU's unwillingness to allow the operation of competing tendencies within unions, the communists formed the International Council of Trade and Industrial Unions (1921) (Losovsky 1920 and 1976). 10 During the 1920s and early 1930s, the "Red International Labor Union" competed with the IFTU over the European union movement. On balance, it never dislodged the IFTU but it managed important inroads.

During the mid-1920s efforts of British and Soviet trade-unionists to heal the division were defeated, while the "social- fascism" strategy of the 1928-1934 period created deep wounds between the communists and the socialists. After the ascent of Hitler and the initiation of the "popular front" strategy there were efforts to heal these wounds, with some domestic successes. The RILU itself dissolved but the ascendancy of the right destroyed some of the most important unions, including the German and Spanish ones.

Before we move to the post WWII period it is important to note some additional results of the interwar polarization on international labor politics. Because of the limitations of what they could do in Western Europe the communist organizations sought, with some success, to expand to the rest of the world. Increasingly, therefore, labor organizations came into being in non-European countries or existing ones were brought closer to the European models. In response to the increasing influence of the communists in the non European world, both the IFTU and the AFL also expanded their horizons. During the 1930 s, therefore, we see the political geography of international labor politics becoming more comprehensive and contested, a pattern that continued after WWII.

The polarization between social-democrats and communists as well as long standing political disagreements also led to the creation of the International Federation of Christian Trade Unions (IFCTU) in 1920. The IFCTU brought together both Catholic and Protestant unions and also organized its own Trade Secretariats (starting with 13 in 1922). During the interwar period it grew quite noticeably but never reached the size of the IFTU or the RILU. As with the social democrats, the rise of Nazism deprived it of some of its major unions.

\section{The Cold War: Fighting Along with the State}

Post WWII labor politics were very much affected by the formalization of the Cold War and the "post WWII settlements" that were put in place after a short period of labor mobilizations (in some cases these had started in the 1930s). While these settlements were largely in favor of capital they ranged from the formal incorporation of labor unions 
into state power, as in Mexico, to loose understandings predicated on growth, such as in the US.

The reconstruction period ended soon and, with it, industrial peace. By the late 1960s it was clear that the world economy was returning to pre WWI levels of integration and that its future would be contested between USA liberal internationalists and European socialcapitalists.

The World Federation of Trade Unions. The event that closes the interwar period took place a few years after the end of WWII. The fitful rapprochement between the communists and socialists that had started in the late 1930s was strengthened by WWII, resulting in the formation of the World Federation of Trade Unions in 1945 (Lorwin 1953, Chs. 19-22; Windmuller 1954; and Schevenels 1956). The WFTU brought together the vast majority of unions in Europe, South America and Asia, with the notable exceptions of the AFL and Christian unions. It was accepted as an observer at the United Nations Economic and Social Council (along with the AFL) but its hopes of receiving a special status similar to the ILO were thwarted.

[Page 60]

Journal of World-Systems Research

The AFL was extremely hostile to the WFTU from the very beginning, partly as a result of its long-standing opposition to socialists and communists and partly because the CIO had been made a member of the organization. In fact, the AFL's tactics against the CIO included its monopolization of US representation in the ILO as well as attempts to prevent the $\mathrm{CIO}$ from gaining observer status at ECOSOC.

The WFTU faced additional internal obstacles. One of the WFTU's goals was to make the International Trade Secretariats integral parts of the organization. This met with resistance by a number of ITSs, particularly the International Transport Federation and the International Metalworkers' Federation, to a significant degree as a result of their anticommunism. It was, in fact, the IMF that provided Irving Brown (the AFL's chief European strategist) with the organizational coverage from which to fight the AFL's battle against the WFTU (Macshane 1990 and 1992).

In addition to opposition by the AFL, as well as the British TUC, the policies of the USSR were also hostile to an autonomous WFTU. The end was its split in 1949 into two federations--the International Confederation of Free Trade Unions and the World Federation of Trade Unions. The debate over who was responsible continues (Niethammer 1978; Carew 1984; and Silverman 1993). The ITSs preserved their autonomy but formalized their relationship with the ICFTU.11

The period from the break up of the WFTU to the 1960s should be considered as a period of increasing polarization within international labor politics (Kassalow 1963; Cox 1971; 
Busch 1983). The two major organizations, as well as the ICFTU-related International Trade Secretariats, became transmission belts for the priorities of the interests of US and USSR labor-state alliances. As a result of this competition, the domestic labor politics of more countries outside of Europe became subject to international contestations, a process that can be traced to the interwar period.12 For most of this period, and much of the subsequent period, this expansion took the form of divisive interventions rather than assistance towards the creation of autonomous unions. From both an organizational and a political angle, therefore, there is much to support the "labor imperialism" critique (Cox 1977; Spooner 1989). 13

Transborder Politics from the Right: The Consistency of the AFL. The foreign policy of the AFL highlights, in its consistency, the deep and autonomous inputs of societal forces in shaping world politics. Just before and during WWI, the AFL cautiously entered European politics, continuing to be very suspicious of socialist unions and parties. The hostility of the AFL to the social democrats has had a long history and was initially motivated by Gompers' deep opposition to the Lassalean model of party-union relations. Even before WWI the AFL had encouraged its member unions to join the Trade Secretariats in order to prevent the social-democrats from controlling them as well as using them for making inroads into the Americas (for background, see Lorwin 1929, Ch. 4).

After WWI, the AFL's opposition to the federalization of the IFTU led to its quick withdrawal from the organization. During its brief engagement with European labor politics, however, the AFL was instrumental in promoting and legitimating the ILO, an organization that fell well below the federal powers that the socialists had in mind.

As part of the AFL's post WWI foreign policy, and in order to exert pressure on the Wilson administration, Gompers formed the Pan-American Federation of Labor which lapsed out of existence shortly after his death in 1924 (Snow 1964; Levenstein 1971). For most of the subsequent period the AFL it did not look outward. This changed with the rise of the CIO and the latter's emphasis on international relations. In the late 1930s, partly in response to nazism in Europe but mostly in order to prevent the CIO from getting international recognition, the AFL rejoined the IFTU (Lorwin 1953: 180-181; Windmuller 1954). It also pressed Roosevelt to join the ILO so that it could get the US representation in that organization. In response to the CIO's courting of the leftist Confederation of Latin American Workers (CTAL by its Spanish language initials), the AFL renewed its interests towards the Americas (Levenstein 1971; Godio 1985).

[Page 61]

Journal of World-Systems Research

The AFL stayed out of the World Federation of Trade Unions and placed its energies in breaking up that organization. It also encouraged its members to join the Secretariats in order to prevent them from moving further to the left. In this it was helped by the 
substantial resources that were made available to it from the US government, the staffing of its foreign arm by a group of converted socialists and communists and by the Soviet Union's desire to also control the WFTU (Windmuller 1954).

During the 1940s and 1950s the primary goal of the AFL (and later the AFL-CIO) was to contest the communists, particularly in Europe and South America, and keep the socialdemocrats from making any overtures to communist unions (Godio 1985; Melgar Bao 1988; Welch 1995; Spalding 1992-1993). In the Americas it was instrumental, in collaboration with the corporatist elements within the Confederation de los Trabajadores Mexicanos (CTM), in destroying the CTAL and setting up in its place the Inter-American Regional Workers' Organization (ORIT by its Spanish language initials). ORIT, formally part of the ICFTU but controlled by the AFL-CIO, was used to contain communist and other progressive unions and to support conservative corporatism and business -unionism (Caulfield 1997).

By the late 1960s, the AFL-CIO had lost its sway over the ICFTU. This was the result of reasons both external and internal to the AFL-CIO (Cox 1971). Externally, European reconstruction had brought with it the rebuilding of European unionism, particularly German unions. Moreover, by the late 1960s many of these unions had to confront the radicalization of their societies and increased worker mobilization, thus moving somewhat more to the left. In addition to the changes in Europe, the AFL-CIO's relationship to the US state was also undergoing change. As a result of the growth of overseas investment by US companies as well as competition from other countries, the AFL-CIO moved from a support of free trade to fair trade (Donohue 1992).

In addition to these external factors, the AFL-CIO also had to deal with internal disagreements over strategy. The unification with the CIO transferred important disagreements over international labor politics inside the Federation. While the AFL, mostly composed of craft unions with limited exposure to international competition, felt comfortable articulating its foreign policy around anti-communism, this was not as easy for the $\mathrm{CIO}$ unions. In particular the UAW felt directly threatened by the internationalization of the auto industry while their leadership felt comfortable dealing with some social-democratic European unions (Debouzy 1990; Sagnes 1994, Ch. 21).

As a result of the above developments it became increasingly difficult for the AFL-CIO to control the ICFTU as well as some of the ITSs. The ICFTU came increasingly under the influence of the Continental unions who saw some value to détente and unity. Even amongst the ITSs the AFL-CIO was confronted with efforts at including communist labor unions. As these conflicts were becoming more serious the AFL-CIO withdrew from the ICFTU in 1969, not to return until 1982, after Meany's death (for this period, see Busch 1983).

In the early 1960s the AFL-CIO reorganized its foreign policy arm. From the early 1960 s to the mid 1990s, its foreign policy of the AFL-CIO, outside of Europe, has been carried out through the AIFLD and its regional arms as well as through bilateral arrangements. It 
has been criticized for being an extension of US policy; for being blindly anticommunist; and for promoting business unionism (Sims 1992; Cox 1977).

Yet, the lesson of this brief account is to suggest that it is misleading to paint the Federation as a puppet of the US government with no volition of its own. In fact, for much of its history it has pursued a resolute policy of 'business unionism'. This, moreover, does not mean that it will not engage in international labor politics; only that it will do so under the weight of its long history. Stated otherwise, being an economistic trade union is a political choice that, moreover, does not preclude active engagement in international labor politics to promote a preferred vision of labor and world politics.

\section{From the Late 1960s To the Present: Opportunities, Inertia and the Phantom of Syndicalism.}

The radicalization of the late 1960 s and early 1970 s led to a deepening of the welfare state in a number of industrial countries. In addition, social-democratic governments came into office in much of Europe for the first time since the immediate post WWII period. Nascent labor radicalism never matured, as a consequence. The social democratic response did not last long, however. By the early 1980s it was apparent that, under the leadership of neoliberal alliances, the world capitalist economy was placing overwhelming pressures on social democratic policies. In the meantime, unions had lost precious time in forming their own policies.

[Page 62]

Journal of World-Systems Research

In addition to the attacks on the domestic post WWII settlements, international policies are also at a crossroads. The ILO has reached its limits. Throughout its existence it has helped negotiate a host of international treaties whose implementation depended on national politics. So long as embedded liberalism held its ground, domestic politics and growth could contain capital and make the system work. As neoliberalism becomes more hegemonic, the weaknesses of the ILO are also becoming more apparent. As economic rule making is moving to the global and regional levels, the ILO's role has not been enhanced, nor have new institutions or rules been put in place to re gulate capitalist integration. On the other hand, the WTO and the other institutions of global and regional economic governance are gaining in relative autonomy, directly affecting domestic policies.

The ICFTU. During the 1970s and 1980s the ICFTU and WFTU continued their competitive existence, much of which was played out in Africa and Asia. The post 1989 changes affected deeply the WFTU with a number of unions breaking away and joining the ICFTU. By the middle 1990s the WFTU had suspended its operations. 
At present, the remaining two confederations (the ICFTU and the World Confederation of Labor) cover much of the globe, with the ICFTU being by far the largest and most inclusive. As of the end of August 1997, it had 195 affiliates in 137 countries. In practice, therefore, the one country-one union rule has many exceptions. It is not clear, however, that the organization is moving towards more transocietalism; the members are still national organizations that mediate access to their members at the national border, as it were. Geographically it is present in all five continents but there are no unions from Russia or China. While the weight of its leadership is still from the core, the role of unions from the third world has improved significantly during the last few years. As well developed social-unionist organizations--such as the Brazilian Unified Workers Central (CUT by its Portuguese initials) and the South African Congress of South African Trade Unions (COSATU)--have joined that trend is bound to continue.

Nonetheless, the ICFTU remains a weak intersocietal confederation with limited powers and resources. As the Cold War has withered away and neoliberal hegemony ascended, its marginal role has become more apparent (Waterman 1997, Ch. 5).

Ironically, this does not mean that the Confederation has been impervious to the changes that are unfolding (ICFTU 1979, for example). During the 1970s it promoted the adoption of a code of contact for transnational corporations in various international fora (Enderwick 1985). No binding code was ever signed and ratified. More recently it has articulated its international policies around the inclusion of a social clause in economic agreements (see ICFTU 1996a-d). The ICFTU has also sought to improve its profile in international fora. Compared to its special status at the ILO, however, its standing has declined to that of an NGO amongst others (Waterman 1997, Ch. 5). Increasingly, it has sought to organize parallel meetings in conjunction with the meetings of global institutions, such as the G-7, the WTO, the 1995 Social Summit, or the Summits for the Americas. Those meetings have provided opportunities to forge alliances with other NGOs, opportunities that have not matured into something substantive yet.

Clearly, the ICFTU could raise its profile even if it does not change in any dramatic fashion. In order to move beyond symbolic action, however, it must reorganize internally as well as deal effectively with a number of important problems, particularly regionalism and North-South relations.14 Stated differently, the ICFTU is not a large organization that has lapsed into bureaucratic inertia for political or generational reasons. It is an organization that is historically and purposefully weak. The road to change, therefore, will have to start outside of the organization.

The International Trade Secretariats . Engaging in labor organizing, training, and other collaborative activities may be best left to the Secretariats, even though there are reasons why one should not be too optimistic about their ability to undertake such initiatives.

The number of International Secretariats stands 14, following a pattern of centralization that has been taking place throughout the post WWII era (Windinuller 1995; ICEM 1996). The ITSs have also become more ecumenical in terms of membership, ideology, and geography, while a number of them have grown organizationally. $\underline{15}$ 
[Page 63]

Joumal of World-Systems Research

By comparison to the pre 1960 s era, more ITSs have moved beyond the gathering of information and their symbolic functions. Some have enhanced their role at IGOs and improve their solidarity work and have sought to coordinate cross -border activities (Levinson 1972; Neuhaus 1982; Bendiner 1987; Sagnes 1994, 506; Labor Research Review 1993 and 1995; and Windmuller 1995). Even though their successes have been limited, this trend is important to note because the common perception is one of continuous decline of the internationalist impetus amongst labor unions.

Given their membership, Secretariats should allow for easier transocietal contacts. Even so, they have not facilitated autonomous horizontal contacts but have been opposed to them. Intersocietalism, therefore, remains quite strong and even activists do not know what the ITSs are, what they do, and what they can do. 16 While, for both organizational and programmatic reasons, the Secretariats are better suited for direct involvement in international labor organizing, there is nothing automatic about this, as the experience of the World Company Councils suggests.

The World Company Councils emerged during the 1960 s as a result of the initiatives of the UAW within the International Metal Workers Federation (Busch 1983: 192-202;

Bendiner 1987). Subsequently this strategy was taken up by the International Federation of Chemical and General Workers' Union (ICF) (Levinson 1972). By the late 1970s there were dozens of them, if often only on paper. Their membership consisted of the labor forces of individual MNCs or MNCs within the same sector. Their long term goal was transnational collective bargaining. The promise of this innovation was such that at least one major business study dealt with the issue exhaustively during the 1970s (Northrup and Rowan 1979; Rowan, Northrup and O'Brien 1980; and Rowan, Pitterle and Miscimarra 1983).

There were a number of obstacles that eventually doomed the WCCs. First, since they emanated from the ICFTU camp there was limited enthusiasm in including members from WFTU unions--a major problem in France and Italy. It was not only the continuing divisions within labor politics that affected the WCCs. Another problem was the fact that they were conceived and seen as instruments for the 'established worker' raising the possibility of a neo-craftist approach to labor organization (for a critique, see Olle and Schoeller 1977). In addition, there were serious disagreements amongst European and US unionists, who did not share a common discourse or politics, and the jealous desire of unions and ITSs to prevent WCCs from creating autonomous horizontal linkages. More recently there have been efforts to revive the WCC strategy, a prime example being the IMF's Bridgestone Council. The current revival, however, aims at establishing horizontal communication networks and at supporting local organizing and bargaining. If those horizontal networks are allowed to grow and gain in autonomy, we can foresee the contestation of international labor organizations from the inside. 
The European Trade Union Confederation (ETUC). An important development that highlights the divisions as well as the opportunities within international labor politics was the formation of the ETUC. Motivated by the mobilizations of the late 1960s and early 1970 s and openings in the European integration project, European unions started the process of formalizing their regional representation (Barnouin 1986; Visser and Ebbinghaus 1992). This process has been painfully slow for two reasons. First, differences amongst the member unions and, second, unwillingness of the EEC to establish supranational labor policy-making until the late 1980s.

As the ETUC started taking shape it gave rise to major debates over its relationship with the ICFTU and the ITSs (Kirchner 1980). Particularly concerned was the AFL-CIO, which had remained involved in the ITSs, and saw the ETUC and its sectoral organizations as a step towards the reassertion of European union hegemony over international labor politics. This concern was aggravated as a number of European unions envisioned opening the ETUC to communist unions. The AFL-CIO's strong role in supporting Solidarity, for instance, can be seen in both the context of its anti-communism and its competition with the European social-democrats as well as the World Confederation of Labor (who was also active in Eastern Europe).

[Page 64]

Journal of World-Systems Research

By now, the ETUC includes all major European unions, including the French CGT, ending the last noticeable cleavage amongst the continent's unions. The relationships between the ETUC and the ICFTU, however, remain an issue of concern, noted during the ICFTU's 1996 meeting (ICFTU 1996a). The relationships between regional organizations, particularly autonomous ones like the ETUC, and global labor organizations is a very important issue in my view. The possibility of competitive regionalism (similar to competitive nationalism) is not impossible, particularly given the long standing discomfort between the AFL-CIO and the social- democrats. Bridging this gap will allow labor to explore the slim opening that the European Works Councils offer.17 Many of these EWCs will be in non-European MNCs. In fact, the ETUC and the AFL- CIO have initiated a process of collaboration, without a doubt a positive step. European, Japanese and US unions could choose to collaborate through bilateral or trilateral arrangements. Policies that seem to be directed against the rest of the world, however, are bound to aggravate North-South divisions. Labor regionalism must be embedded within broader global rules if it is not to degenerate. The ICFTU as well as the ITSs can play an important role in facilitating communication and collaboration. As the discussion that follows insinuates, the redirection of investment to selected countries of the South is giving the unions of those countries influence that they have not had until now. The Northern unions will be well served to respond intelligently to this development before they run out of interlocutors in the South. 
North-South. The process of North American and American integration points to the problems of reconciling North-South divisions. Historically, the ORIT has been an instrument of AFL-CIO politics. In the last few years there have been efforts to revitalize it, with the Canadian and Brazilian unions playing a leading role. As a result, the organization has held parallel meetings in conjunction with the Summits of the Americas. Its demands that labor representatives be included in the deliberation processes have been rejected, further underscoring labor's marginalization. Nonetheless, ORIT continues to call for the inclusion of labor protections and rights in any trade agreement, a call that is consistent with the ICFTU's as well as the AFL-CIO's policy preferences. At the most recent meeting in Bello Horizonte, however, the Mexican and Peruvian governments refused to accept the report of the parallel meeting (The Morning NAFTA, Issue No. 9, June 1997, p.2). Given the Mexican Workers' Federation organic relationship with the Mexican government as well as its opposition to the attachment of any labor rules to NAFTA, it is most likely that the CTM favors its government's policy. In general, the 'nationalist' resistance of conservative corporatist unions could well be adopted by unions in countries, such as Mexico, China, or Malaysia, where predatory developmentalist alliances are in power.

In my view, the concerns of a number of unions and activists from the South regarding some of the motives behind including labor and environmental standards in economic agreement are well placed. On the other hand, a number of unions from the South are using a 'thirdworldist' rhetoric to defeat any policies at all as well as defeat domestic labor opposition. In this they are no different from a number of unions form the North. If leading unions from the North and the South who are in favor of concrete international labor policies do not address the valid concerns, misunderstandings and disagreements amongst them will deepen and predatory unionism will prevail.

[Page 65]

Journal of World-Systems Research

\section{Concluding Comments}

What lessons can be drawn from this historical outline? One lesson is that we should not, a priori, place more emphasis on factors external or internal to labor. Unions, even the socalled business unions, are deeply political (Logue 1980). Thus, the end of the Cold War and deepening regional and global integration are as much a challenge as they are an opportunity. Top down unionism that is impervious to the unprotected worker, social justice, regionalism, and North-South divisions can easily provide divisive wedges that will allow capital, neoliberal states, and certain unions to create new divisions within labor.

The second lesson is that international labor organizations are not simply sleeping gian ts. These are fundamentally weak intersocietal confederations. Accordingly, the central task confronting activist unions is not to simply mobilize them. Most importantly, they need to address their inherent organizational and political weaknesses. Policy entrepreneurs at 
the international level can play a catalytic role if they have the support of key unions. Long term change, however, will come from shifting the energies of activist unions towards international politics in order to contest the nature of the existing organizations or, if necessary, form new ones. Labor activists, therefore, have to engage in a 'war of position' within labor before they can envision a 'war of movement' (for additional discussion see Stevis and Boswell 1997).

There are real and, in my view, desirable, limitations to how much the ICFTU can and should change. Historically it has been a weak intersocietalist organization made up of national units, many of which are themselves weak confederations. Without a doubt much should be done to make the organization more federal and transfer meaningful resources to it.

Yet, I believe that there are real differences amongst the labor unions of the world (differences based on domestic laws and industrial relations, ideology, and historical legacies) that cannot be wished away. The ICFTU and regional organizations will better serve international labor politics by gaining relative autonomy with respect to particular functions, such as the prevention and resolution of inter-union disputes, the delegitimation of company and other puppet unions, the debate and promotion of common policies, and the undertaking of campaigns and activities that will help the world's unions focus their attention towards common or complementary goals.

As with domestic politics, organizing and collaboration are necessary components of a proactive international labor politics. International Trade Secretariats can provide some avenues for such activities (but not the only ones and, often, not the preferred ones). First, they bring together the labor organizations directly engaged in organizing. Second, there is one less layer between an activist union and a Secretariat than there is between and activist union and the ICFTU. Yet, these organizations are also in need of change. While seemingly transocietal they are, in fact, jealously intersocietal.

In short, it is true that current international labor organizations are not adequate to the task of offering some governance and preventing the aggravation of potentially centrifugal dynamics. At the end of the day, however, the issue is not whether these organizations are salvageable but whether labor does need international organizations. In my view, it does need a multitiered system of networks and governance that must include organizations. I will close by addressing a number of select issues that militate, in my view, in favor of such an unparsimonious solution.

While neoliberal integration requires international labor politics it is not true that domestic politics is either useless or politically undesirable. To criticize domestic politics in favor of a nebulous cosmopolitan discourse is dangerous for two reasons. First, because it implies that national politics is a priori malign and international politics emancipatory in some fashion; second, because it reifies capital mobility and assumes that domestic political power is irrelevant to the neoliberal project. Decisions by neoliberal alliances must be held up to the national audience for what they are - decisions by specific social forces representing particular priorities. 
The same logic applies to international politics. Capitalist integration should not obscure the leading role of regional and global state agencies in promoting integration and increasingly managing it. Capitalist integration is based on rules that are promoted, legitimated, and enforced by state institutions. Simply lobbying at the doorsteps of the WTO or the G-7, however, is practically inadequate while, politically, it further deepens capitalist hegemony.

States are not just their immediate institutions and practices; they are, also, the deeper set of rules that constitutes the state and its relations with its environment. Contesting state power, therefore, must go beyond instrumental negotiations to challenge the core rules that undergird neoliberal hegemony. Clearly, the most immediate step is organizing. But, organizing without political and organizational vision is a dangerous panacea.

I believe that cross-border organizing and new organizational forms, particularly those that combine transocietalism with federal or unitary organizations, are important both in themselves and in motivating change in the existing national and international labor organizations (or as a prelude to new ones). But, it is equally necessary that societal politics be contested, whether at the domestic, regional, or global levels. Privileging societal politics while demonizing state power is no different from privileging statism while demonizing societal politics.

[Page 66]

Journal of World-Systems Research

Cross-border or national societal politics are in no way pristine nor uniform. Labor movements come in many hues, some less emancipatory than other. Very few of them are programmatically disinterested in questions of political power while most of them explicitly reinforce the interstate system by locating the boundaries between societal forces along state boundaries.

In short, societal politics must be dissected and unbundled in terms of political and organizational preferences and strategies (Nye and Keohane 1971; Harrod 1972; Wapner 1996; Waterman 1988 and 1997; Boli and Thomas 1997; Moody 1997). Evidence of the contested nature of labor politics, a prominent example of global civil societal politics, will go a long way in supporting the necessity of such a critical approach. Such an exercise should be ready to confront the fact that preferred movements can go astray and/or produce undesirable results because, after all, people do make history but not under circumstances of their own making.

This brings me to my last observation, i.e., that the decline and compromise of communist and socialist parties in most of the world is the third component of the window of opportunity facing labor. Increasingly, labor unions are called upon to formulate and implement their own responses to neoliberal integration. Their traditional political parties have moved to the right or are unable to represent them. What are the 
options, then? One option is for unions to trail their allies. The other option is for labor unions to enhance their autonomy. Becoming more autonomous will require the formulation of broader alliances and agendas. They cannot expect parties to do this for them; nor can they count on a privileged relationship with the state to deliver the material goods. Labor unions, therefore, are confronted with the need for a modicum of syndicalism decades after the latter's premature demise.

\title{
Frequently Used Acronyms
}

AFL

\author{
American Federation of Labor \\ CGT \\ Confédération Générale du Travail \\ $\mathrm{CIO}$ \\ Congress of Industrial Organizations \\ CTM \\ Confederatión de los Trabajadores Mexicanos \\ ECOSOC \\ Economic and Social Council of the United Nations
}

ETUC

European Trade Union Confederation

FI

First International

$\mathrm{ICEF} / \mathrm{ICF}$

International Federation of Chemical and General Workers' Unions

IFTU

International Federation of Trade Unions

ICFTU

International Confederation of Free Trade Unions

IFCTU

International Federation of Christian Trade Unions

ILO

International Labor Organization

ITS

International Trade Secretariat

IWW

Industrial Workers of the World

ORIT

RILU

Inter-American Regional Workers' Organization

Red International of Labor Unions

WCL

World Confederation of Labor

WFTU 


\author{
World Federation of Trade Unions \\ WTO \\ World Trade Organization \\ SSI \\ Second Socialist International

\section{References}

Armstrong, Sinclair. 1942. "The Internationalism of the Early Social Democrats of

Germany". American Historical Review, 47, 2 (January): 245-258.

Barnouin, Barbara. 1986. The European Labour Movement and European Integration. London: Frances Pinter.

Bendiner, Burton. 1987. International Labor Affairs: The World Trade Unions and the Multinational Companies. Oxford: Clarendon Press.

Boli, John and George Thomas. 1997. "World Culture in the World Polity." American Sociological Review 62, $3: 171-190$.

Boyd, Rosalind E., Robin Cohen and Peter C.W. Gutkind (eds). 1987. International Labour and the Third World: The Making of a New Working Class. Aldershot, England: Avebury.

Braunthal, Julius. 1967/1961. History of the International: Volume 1: 1864-1914. NY:

Frederick A. Praeger, Publishers.

Braunthal, Julius. 1967/1963. History of the International: Volume 2: 1914-1943. NY:

Frederick A. Praeger, Publishers.

Braunthal, Julius. 1980/1971. History of the International: Volume 3: $1943-1968$.

Boulder, CO: Westview Press.

Brissenden, Paul Frederick, 1919. The I,W.W.: A Study of American Syndicalism. NY:

Columbia University.

Busch, Gary K. 1983. The Political Role of International Trades Unions. NY: St. Martin's Press.

[Page 67]

Journal of World-Systems Research

Carew, Andrew. 1984. "The Schism within the World Federation of Trade Unions:

Government and Trade-Union Diplomacy". International Review of Social History 29;

297-335. 
Carew, Andrew, 1996. "Conflict within the ICFTU: Anti-Communism and AntiColonialism in the 1950s". International Review of Social History 41: 147-181.

Carr, E.H. 1982. Twilight of the Comintern, 1930-1935. NY: Pantheon Books.

Caulfield, Norman. 1997. "Mexican State Development Policy and Labor

Internationalism, 1945-1958". International Review of Social History 42: 45-66.

Cole, G.D.H. 1954. Socialist Thought: Marxism and Anarchism, 1850-1950. Vol II of his A History of Socialist Thought. NY: Macmillan and Co. Ltd.

Cole, G.D.H. 1958. Communism and Social Democracy, 1914-1931. Volume IV, parts I and II of his A History of Socialist Thought. London: Macmillan and Co Ltd.

Cole, G.D.H. 1960. The Second International, 1889-1914. Vol. III, Pt. I of his A History of Social Thought. London: Macmillan and Co. Ltd.

Cox, Robert. 1971. "Labor and Transnational Relations". Pp. 204-234 in Robert Keohane and Joseph Nye, Jr. (eds), Transnational Relations and World Politics. Cambridge:

Harvard University Press.

Cox, Robert. 1977. "Labor and Hegemony". International Organization 31 (Summer): 385-424.

De Vries, C.W. and J. De Vries (eds). 1949. Texts Concerning Early Labour Legislation, I, (1791-1848). Leiden: E. J. Brill.

del Rosal, Amaro. 1975 [1958]. Los Congresos Obreros Internacionales en el Siglo XIX. Barcelona: Ediciones Grijalbo, S.A. [documents].

Debouzy, Marianne. 1990. "Le Mouvement Syndical Americain: Une 'Politique de Puissance"?" Pp. 333-358 in Guillaume Devin (ed), Syndicalisme: Dimensions Internationales. La Garenne -Colombes, France: Editions Europeennes ERASME

Devin, Guillaume (ed). 1990. Syndicalisme: Dimensions Internationales. La GarenneColombes, France: Editions Europeennes ERASME.

Devreese, D.E. 1988. "An Inquiry into the Causes and Nature of Organization: Some Observations on the International Working Men's Association, 1864 - 1872/76". Pp. 283303 in Van Holthoon and Van Der Linden (eds), Internationalism in the Labour Movement, 1830-1940.

Donohue, Peter. 1992. "'Free Trade' Unions and the State: Trade Liberalization's Endorsement by the AFL-CIO, 1943-1962". Research in Political Economy, vol. 13: 173. 
Dutt, R. Palme. 1920. The Two Internationals. London: George Allen and Unwin.

Enderwick, Peter. 1985. Multinational Business and Labour. NY: St. Martin's Press.

Esping-Andersen, Gosta. 1990. The Three Worlds of Welfare Capitalism. Princeton, N.J.: Princeton University Press.

European Commission. 1996. Agreements on Information and Consultation in European Transnationals. Social Europe, Supplement 5/95. Luxembourg: Office for the Official Publications of the European Community.

[Page 68]

Journal of World-Systems Research

Freymond, Jaques (ed). 1962. La Premiere Internationale. 2 vols [of documents]. Geneva: Librairie E. Droz.

Godio, Julio. 1985. Historia del Movimiento Obrero Latinoamericano/3:

Socialdemocracia, Socialcristianismo y Marxismo, 1930-1980. Caracas: Editorial Nueva Sociedad.

Harrod, Jeffrey 1972 Trade Union Foreign Policy: a Study of British and American Trade Union Activities in Jamaica. Garden City, NY: Doubleday.

Horne, John N. 1991. Labour at War: France and Britain 1914-1918. Oxford: Clarendon Press.

Hulse, James W. 1964. The Forming of the Communist International. Stanford: Stanford Univ. Press.

ICFTU. 1979. Trade Unions and the Transnationals: A Handbook for Negotiators. Brussels: ICFTU.

ICFTU. 1996a. "ICFTU Policies Adopted by the 16th World Congress of the ICFTU". URL: http:/www.icftu.org/english/econgpol.html

ICFTU. 1996b. Behind the Wire: Anti-Union Repression in the Export Processing Zones. Brussels: ICFTU

ICFTU. 1996c Not Time to Play: Child Workers in the Global Economy. Brussels: ICFTU

ICFTU [Natacha David]. 1996d. Un Monde a part: Les Femmes et L'Economie Mondiale. Brussels: ICFTU. 
ICFTU. 1997. The ICFTU: What It Is, What It Does. URL:

http:/www.icfty.org/english/eicwiwd.html

ICEM [International Federation of Chemical, Energy, Mine and General Workers' Unions]. 1996. Power and Counterpower: The Union Response to Global Capital. London: Pluto Press.

Kassalow, Everett (ed). 1963. National Labor Movements in the Postwar World.

Evanston, Ill: Northwestern University Press.

Katz, Henryk. 1992. The Emancipation of Labor: A History of the First International. NY: Greenwood Press.

Kirchner, Emil. 1980. "International Trade Union Collaboration and the Prospect for European Industrial Relations". Pp. 124-138 in Jack Hayward (ed), Trade Unions and Politics in Western Europe. London: Frank Cass.

Knudsen, Knud. 1988. "The Strike History of the First International". Pp. 304-335 in Van Holthoon and Van Der Linden (eds), Internationalism in the Labour Movement, 18301940. Leiden: E.J. Brill

Kriegel, Annie. 1970. Les Internationales Ouvrieres (1864-1943), Paris: Presses

Universitaires de France.

Labor Research Review, No. 21. 1993. "No More Business as Usual: Labor's Corporate Campaigns". Chicago: Midwest Center for Labor Research.

Labor Research Review, No. 23. 1995. "Confronting Global Power". Chicago: Midwest Center for Labor Research.

[Page 69]

Journal of World-Systems Research

Levenstein, Harvey A. 1971. Labor Organizations in the United States and Mexico: A History of their Relations. Westport, Conn.: Greenwood Publishing Company.

Levinson, Charles. 1972. International Trade Unionism. London: George Allen and Unwin.

Logue, John. 1980. Towards a Theory of Trade Union Internationalism. Hent: Kent Popular Press [Copenhagen: Univ of Copenhagen Press.]

Lorwin, Lewis L. 1929. Labor and Internationalism. NY: The Macmillan Co. 
Lorwin, Lewis L.. 1953. The International Labor Movement: History,Policies, Outlook. NY: Harper and Brothers Publishers.

Low, Boutelle Ellsworth. 1921. The International Protection of Labor. NY: The Macmillan Company.

Losovsky, A. 1920. The International Council of Trade and Industrial Unions. New York: The Union Publishing Association.

Lozovskii, A. 1976. L'International Syndical Rouge. Paris: F. Maspero

Macshane, Denis. 1990. "Reflexions sur l'histoire de la Federation Internationale des Ouvriers de la Metallurgie (FIOM)". Pp. 267-296 in Guillaume Devin (ed),

Syndicalisme: Dimensions Internationales. La Garenne-Colombes, France: Editions Europeennes ERASME.

Macshane, Denis. 1992. International Labour and the Origins of the Cold War. Oxford: Clarendon Press.

Mann, Michael. 1993. The Sources of Social Power. Vol. II. The Rise of Classes and Nation-states, 1760-1914. New York: Cambridge University Press.

Melgar Bao, Ricardo. 1988. El Movimiento Obrero Latino-Americano. Madrid: Allianza America.

Milner, Susan. 1990. The Dilemmas of Internationalism: French Syndicalism and the International Labour Movement, 1900-1914. New York: Berg.

Mommsen, Wolfgang J. and Hans-Gerhard Husung (eds). 1985. The Development of Trade Unionism on Great Britain and Germany. 1880-1914. London: George Allen (for The German Historical Institute).

Moss, Bernard H. 1976. The Origins of the French Labor Movement: The Socialism of Skilled Workers. Berkeley: University of California Press.

Munck, Ronaldo. 1988. The New International Labour Studies: An Introduction. London: Zed Books.

Moody, Kim. 1997. Workers in a Lean World: Unions in the International Economy. Verso.

Neuhaus, Rolf. 1982. International Trade Secretariats: Objectives, Organisation, Activities. Kingston, Jamaica: Friedrich-Ebert-Stiftung.

Niethammer, Lutz. 1978. "Structural Reform and a Compact for Growth: Conditions for a United Labor Union Movement in Western Europe after the Collapse of Fascism". Pp. in 
Charles Maier (ed), The Origins of the Cold War and Contemporary Europe. NY: New

Viewpoints.

Nin, Andreu. 1977. Las Organizaciones Obreras Internacionales. Madrid: Ediciones de la Torre.

[Page 70]

Journal of World-Systems Research

Northrup, Herbert R. and Richard Rowan. 1979. "Multinational Collective Bargaining Attempts: The Record, the Cases and the Prospects". Multinational Industrial Relations Series, no. 6. Philadelphia: Industrial Research Unit, The Wharton School, University of Pennsylvania.

Nye, Joseph, Jr. and Robert Keohane. 1971. "Transnational Relations and World Politics: A Conclusion". Pp. 371-398 in Robert Keohane and Joseph Nye, Jr. (eds), Transnational Relations and World Politics. Cambridge: Harvard University Press.

Olle, Werner and Wolfgang Schoeller. 1977. "World Market Competition and Restrictions Upon International Trade Union Policy". Capital and Class No. 2 (Summer).

Pasture, Patrick. 1994. Christian Trade Unionism in Europe Since 1968: Tensions

Between identity and Practice. Aldershot, UK: Avebury.

Postgate, R.W. 1921. The Worker's International. London: The Swarthmore Press Ltd and the Labour Publishing Co. Ltd.

Reberioux, Madeleine. 1990. "Naissance du Secretariat Typographique International". P. 37-52 in Guillaume Devin (ed), Syndicalisme: Dimensions Internationales. La GarenneColombes, France: Editions Europeennes ERASME.

Roberts, B.C. 1981. "Multinational Enterprise and Labour". Pp. 365-400 in Peter B. Doeringer et al (ed), Industrial Relations in International Perspective: Essays on Research and Policy. New York: Holmes and Meier Publishers, Inc.

Rowan, Richard L., Hebert R. Northrup and Rae Ann O'Brien. 1980. Multinational Union Organizations in the Manufacturing Industries. Industrial Research Unit, The Wharton School, University of Pennsylvania.

Rowan, Richard L., Kenneth J. Pitterle and Philip A. Miscimarra. 1983. Multinational Organizations in the White-Collar, Service, and Communications Industries. Industrial Research Unit, the Wharton School, University of Pennsylvania. 
Rutters, Peter. 1990. "Histoire et Developpment des Secretariats Professionels Internationaux (SPI)". Pp. 251-266 in Guillaume Devin (ed), Syndicalisme: Dimensions Internationales. La Garenne-Colombes, France: Editions Europeennes ERASME.

Sagnes, Jean (ed). 1994. Histoire du Syndicalisme dans le Monde: Des Origines a nos Jours. Toulouse, France: Edition Privat.

Sassenbach, J. 1926. Twenty-Five Years of International Unionism. Amsterdam: International Federation of Trade Unions.

Schevenels, Walther. 1956. Forty-Five Years: International Federation of Trade Unions. Brussels: Board of Trustees, IFTU.

Shotwell, James T. (ed). 1934. The Origins of the International Labor Organization. 2 vols. NY: Columbia U. Press.

Silverman, Victor. 1993. "Popular Bases of the International Movement in the United States and Britain, 1939-1949". International Review of Social History 38: 301-320.

Sims, Beth. 1992. Workers of the World Undermined: American Labor's Role in U.S. Foreign Policy. Boston: South End Press.

[Page 71]

Journal of World-Systems Research

Southall, Roger (ed) 1988. Trade Unions and the New Industrialization of the Third World. London: Zed Books

Spooner, Dave. 1989. Partners or Predators: International Trade Unionism and Asia. Hong Kong: Asia Monitor Resource Center.

Spalding, Hobart. 1992-1993. "The Two Latin American Foreign Policies of the U.S. Labor Movement: The AFL-CIO Top Brass vs. Rank-and-File". Science and Society 56 (4): 421-439.

Stekloff, G. M. 1928. History of the First International. New York: International Publishers.

Stevis, Dimitris and Terry Boswell. 1997. "Labour: From National Resistance to International Politics." New Political Economy 2, 1: 93-104.

Sturmthal, Adolph. 1944. The Tragedy of European Labour, 1918-1939. London: Victor Gollancz, Ltd. 
Thorpe, Wayne. 1989. "The Workers Themselves": Revolutionary Syndicalism and International Labour, 1913-1923. Dordrecht: Kluwer Academic Publishers and International Institute of Social History, Amsterdam.

Thorpe, Wayne. 1990. "Syndicalist Internationalism Before World War II". In Marcel Van der Linden and Wayne Thorpe (eds), Revolutionary Syndicalism: an International Perspective. Aldershot: Scolar Press (Gower).

Tilly, Charles. 1995. Globalization Threatens Labor's Rights. International Labor and Working-Class History 47 (Spring): 1-23.

US. Department of Labor. Bureau of Labor Statistics. 1919. International Labor Legislation and the Society of Nations. Bulletin of the United States Bureau of Labor Statistics, no. 254. Translation of work by Stephan Bauer. Washington: GPO.

Van der Linden, Marcel and Wayne Thorpe (eds) 1990. Revolutionary Syndicalism: an International Perspective. Aldershot: Scolar Press (Gower).

Van Der Slice, Austin. 1941. International Labor, Diplomacy and Peace, 1914-1919. Philadelphia: University of Pennsylvania Press.

Van Holthoon, Frits and Marcel Van Der Linden (eds). 1988. Internationalism in the Labour Movement, 1830-1940. 2 vols. Leiden: E. J. Brill.

Visser, Jelle and L. Ebbinghaus. 1992. "Making Most of Diversity? European Integration and Transnational Organization of Labour". In J. Greenwood, J.R. Grote and K. Ronit (eds), Organized Interests in the European Community. Beverley Hills: Sage Publications.

Wapner, Paul. 1996. Environmental Activism and World Civic Politics. State University of New York Press.

Waterman, Peter. 1988. "The New Internationalisms: A more Real Thing than Big, Big Coke?" Review 11 (3): 289-328.

Waterman, Peter. 1997. From Labour Internationalism to Global Solidarity. Unpublished manuscript.

Welch, Cliff. 1995. "Labor Internationalism: U.S. Involvement in Brazilian Unions, 1945-1965". Latin American Research Review 30 (2): 61-89.

Wheeler, Robert F. 1977. "Revolutionary Socialist Internationalism: Rank-and-File Reaction in the USPD". International Review of Social History 22, part 3: 329-349.

[Page 72]

Journal of World-Systems Research 
Windmuller, John P. 1954. American Labor and the International Labor Movement 1940 to 1953. Ithaca: Cornell University Press.

Windmuller, John P. 1980. The International Trade Union Movement. Deventer: Kluwer.

Windmuller, John P. 1995. International Trade Secretariats: The Industrial Trade Union Internationals. U.S. Department of Labor. Bureau of International Labor Affairs. Foreign Trends, Special Report. Washington, D.C.

World Confederation of Labor. 1969. From IFCTU to WCL. Brussels.

\section{Endnotes}

1 I am particularly indebted to the comprehensive and succinct overviews by Sagnes (1994), particularly chapters 7 and 21 . I have found these two chapters to be the most sophisticated comprehensive accounts of international labor politics. Also see Windmuller (1980) and Kriegel (1970). Additional references are provided with respect to each period.

2 For background see Postgate (1920); Steckloff (1928); Lorwin (1929); Cole (1954); Freymond (1962 [documents]); Devreese (1988); various articles in Van Holthoon and Van der Linden (1988); and Katz (1992).

$\underline{3}$ The first of these International Trade Secretariats, as well as the first gathering of what eventually became the Second International, took place during the Centennial of the taking of the Bastille. The First International was formed during an international trade fair. In general, these international fairs and meetings may have played the same role that various international meetings with their parallel citizens' summits play today.

4 Because of this two additional labor movements took shape. One was that of the Christians who started their first international meetings before WWI. Christian unionism was particularly opposed to the class-struggle approach of the socialists. In addition, a number of unions and groups influenced by syndicalism became increasingly disenchanted or marginalized and just before WWI they formed the International Working Men's Association (see Thorpe 1989 and 1990; Van der Linden and Thorpe 1990).

$\underline{5}$ Generally speaking, much of the literature on state power and autonomy does not adequately differentiate politics emanating and directed by social forces internal to or derivative of the state from politics that is the result of societal forces taking over, changing, and using the state. 
$\underline{6}$ See Lorwin (1929, 1953); Strumthal (1944); Cole (1958); Braunthal (1967/1963); and Nin (1977).

7 The International Trade Secretariats were reconstituted immediately after WWI. Most of them were now located outside of Germany and were under the hegemony of the IFTU, but some did preserve a significant degree of independence. Due to the activism of the IFTU and the intensity of the subsequent conflicts, the ITSs remained even more inactive than they had been before WWI. One important exception was the International Transport Federation. There were 27 ITSs before WWII.

$\underline{8}$ For background see Dutt (1920); Lorwin (1929, Chs. 10, 14, 20 and 21); Lorwin (1953); Cole (1958); Braumthal (1967/1963, Chs. 7,10 and 13); and Hulse (1964).

[Page 73]

Journal of World-Systems Research

9 The Third International depended on its funding and leadership on the Bolsheviks from the very beginning. For a number of years, perhaps as late as 1928 , it retained a vision geared towards world transformation rather than simply carrying on Soviet foreign policy.

10 The syndicalists participated in the Third International and the Red International of Trade Unions (RILU), as the Council came to be known, during the early years. They were opposed to the dominant role of the party and the Third International over labor unions. Their cohabitation with the communists did not last long, with the syndicalists eventually joining their own international, the International Working Men's Association, based in Berlin.

11 The final break, however, suggests an interesting departure from what we would expect given the Cold War cleavage and the statization of labor. Two major unions, the French Confédération Générale du Travail(CGT) and the Italian Confederazione Generale Italiana del Lavoro (CGIL) stayed within the WFTU. These exceptions, along with the continuing independence of the Christian unions, underscore the significance of factors internal to labor organizations.

12 The expansion of the ICFTU into the decolonizing countries was the subject of much debate within the ICFTU, pitting the British and French unions against the AFL-CIO (Carew 1996).

13 To this expansion of the arena of international labor politics we can also add the role of the IFCTU. Recognizing that it could not compete with the WFTU and the ICFTU in Europe, it placed its energies in Africa, Latin America and Asia. During the 1950s it formed a regional organization in Latin America and brought non-European unionists into its leadership. By 1961, African delegates accounted for $37 \%$ and Latin American 
delegates for $29 \%$ of those participating at its congress. In 1968 the IFCTU moved to the left, abandoning its denominational character and adopting a stronger class-struggle approach. At that point it changed its name into World Confederation of Labor (WCL) (World Confederation of Labor 1969; Godio 1985; Pasture 1994).

14 The IFCTU has three regional components: the Asian and Pacific Regional Organization (APRO), the African Regional Organization (AFRO), and the InterAmerican Regional Organization of Workers (ORIT). The first two are not particularly active. The ORIT has traditionally been controlled by the AFL-CIO. In light of recent changes in the Americas and the AFL-CIO, there are efforts to revitalize it. The European Confederation of Trade Unions is not a regional organization of the ICFTU. More on this later.

15 Many ITSs have grown organizationally during the last thirty years. Yet, they are more networks rather than organizations, perhaps with two or three exceptions. As a result, the activism of ITSs can vary depending on the priorities of leading unions within them. Consistently with the above it is possible for an ITS to be more active in particular regions or sectors, reflecting union priorities. In general, however, the most active organizations have been the International Union of Food and Allied Workers' Associations (IUF), the International Federation of Chemical, Energy, and General Workers' Unions (ICEF) and the International Metalworkers' Federation (IMF). The ICEF and the International Miners' Federation fused in 1995 (ICEM 1996).

16 The Secretariats are a prime example of how 'transnational' relations can very much solidify intersocietalism. The Secretariats, through omission or prohibition, have strengthened intersocietalism at the sectoral level.

[Page 74]

Journal of World-Systems Research

17 Large multinational concerns are now required to set up a Work Council that brings together worker (not necessarily unionized) representatives from the various European countries in which they operate. These Councils must be consulted but do not have decision-making powers. The Councils can easily turn into public relations opportunities for MNCs (for background see European Commission 1996).

[Page 75]

Joumal of World-Systems Research 